\title{
Rearing and spawning technique of Clown Loach (Chromobotia macracanthus, Bleeker 1852) in Research Institute for Ornamental Fish Culture of Depok, Indonesia
}

Mita Winarti ${ }^{1}$, Asep Permana², Darmawan Setia Budi ${ }^{1,3, *}$

${ }^{1}$ Aquaculture program, PSDKU University of Airlangga, Jl. Wijaya Kusuma No. 113, Kec. Giri, Banyuwangi, East Java, Indonesia

${ }^{2}$ Ornamental Fish Cultivation Research Center, Jl. Perikanan, No. 13, Pancoran Mas, Depok 16436,

West Java, Indonesia

${ }^{3}$ Department of Fish Health Management and Aquaculture, Faculty of Fisheries and Marine Science,

University of Airlangga, Jalan Mulyosari, Surabaya 60113, East Java, Indonesia.

*darmawansetiabudi@fpk.unair.ac.id

${ }^{*}$ Corresponding author

\begin{tabular}{|l|l|}
\hline ARTICLE INFO & ABSTRACT \\
\hline $\begin{array}{l}\text { Keywords: } \\
\text { Botia } \\
\text { Fertility } \\
\text { Hatching rate } \\
\text { Ovaprim }\end{array}$ & $\begin{array}{l}\text { The high demand of Clown Loach or botia fish (Chromobotia } \\
\text { macracanthus) in the market lead to its sustainability in nature being } \\
\text { threatened. The purpose of this technical report is to describe the }\end{array}$ \\
\hline $\begin{array}{l}\text { broodstock and spawning techniques of botia fish carried out at the } \\
\text { Research and Cultivation Center for Freshwater Ornamental Fish } \\
\text { (BRBIH) Depok, West Java. This activity was carried out from December } \\
\text { 2019 to January } 2020 . \text { This study used two female cows with a } \\
\text { spawning ratio of } 3: 1 . \text { The average length of the female parent is } 9.5 \\
\text { cm with an average weight of } 33.5 \mathrm{~g}, \text { while the length of the male } \\
\text { parent is } 15.3 \mathrm{~cm} \text { with an average weight of } 56.3 \mathrm{~g} \text {. Spawning is done } \\
\text { artificially using ovaprim. The result of this study was the fecundity } \\
\text { value of an average of } 8,453 \text { eggs / ind. The average FR was } 86.15 \%, \\
\text { and the average HR was } 78.15 \% \text {. }\end{array}$ \\
\hline
\end{tabular}

How to cite:

Winarti M, Permana A, Budi DS. 2020. Rearing and spawning technique of Chromobotia macracanthus, Bleeker 1852 in Research Institute for Ornamental Fish Culture of Depok, Indonesia. IJOTA, 3(2): 53-58.

DOI: https://doi.org/10.22219/ijota.v3i2.13649

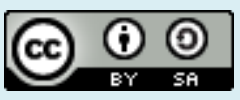

\section{Introduction}

Clown Loach or Botia fish (Chromobotia macracanthus) is an ornamental fish endemic to Indonesia originating from Kalimantan and Sumatra. Botia fishes in Kalimantan are scattered in the Barito, Kahayan, Kapuas, Mahakam and Bongan rivers. Meanwhile in Sumatra, these fishes are 
scattered in the Pengabuang River, Kwanten, Batanghari, Musi and their River Schools (Ghofur \& Harianto, 2018). Botia fishes are in great demand by the global community because they have a small, flat and elongated body morphology and have a bright yellow body color with three broad stripes or wide black bands so they are suitable to be kept in an aquarium as ornamental fish. Botia fish exports have increased from year to year. The export value of botia fish in 2017 in the January to October period reached 424450 fish with the export frequency was 47 times (Ariyanto et al, 2019). In 2018 the export of botia fish has increased to reach 596939 fish.

Currently, the availability of botia broodfish still mostly relies on natural catches (Ghofur \& Harianto, 2018). However, the availability of fish, apart from relying on natural catch, has also been developed for laboratory-scale artificial hatcheries (Ghofur et al, 2018). The high demand for botia fish in the market has resulted threatened its sustainability in nature (Ghofur \& Harianto, 2018). Botia fish farming is a solution to meet market needs without depending on nature. One of the stages of the fish farming is hatchery which consists of broodstock cultivation and fish spawning (Tridjoko et al, 1996). The process of cultivating the broodfish determines the quality of the offspring. The qualified broodfish can produce qualified offspring when the process of cultivating the broodfish is good. While the spawning process can determine the quality and quantity of the eggs (Kusrini et al, 2015). The study aim to evaluate the broodstock and spawning techniques of botia fish at Balai Riset Budidaya Ikan Hias (BRBIH) Depok, West Java.

\section{Material and methods}

The study was conducted in December 2019 to January 2020 at Balai Riset Budidaya Ikan Hias (BRBIH) Depok, West Java.

\subsection{Preparation of Spawning and Hatching Ground}

The aquarium used for broodfish quarantine was cleaned using fine sandpaper throughout the walls of the aquarium and dried for one day. The dry aquarium was then filled with water as high as $2 / 3$ of the aquarium and left for a day. The tank was made of concrete. The tank was cleaned by rubbing the bottom and inner walls with a cleaning brush and then rinsing with water. The tank was filled until the water reaches $10 \mathrm{~cm}$ from the top surface of the tank and was left for one week. Hapa cloth was installed in the tank with a size of $100 \times 6 \times 58 \mathrm{~cm}$. The hapa cloth was strung with two PVC pipes located at the top and bottom side. Then inside the hapa cloth, a steroform with a size of $87 \times 46.5 \mathrm{~cm}$ was placed which had been given two holes with a diameter of $27 \mathrm{~cm}$. The steroform holes were used to place a fiberglass hatching funnel with a diameter of $26 \mathrm{~cm}$. The end of the funnel was connected to the aeration valve using a $1.3 \mathrm{~cm}$ diameter.

\subsection{Broodfish Selection}

The broodstock of botia fish cultivated in the tanks were selected to obtain the ready spawned broodstock. The female broodstock were cannulated using a catheter to remove eggs from the body of the fish. The eggs were then observed using a stereo microscope to determine the diameter, size uniformity, and level of maturity of the eggs. Male broodstock selection was done by stripping the broodstock stomach to determine which broodstock is ready to be spawned. Male broodstock that is ready to spawn were indicated by the release of sperm when stripping. Male and female broodstock that are ready to spawn are put into separate broodstock quarantine aquariums. 


\subsection{Botia Fish Spawning Stimulation}

The ready spawned broodstock of botia fish were anesthetized using phenoxyethanol at a dose of $0.3 \mathrm{ml} / \mathrm{L}$ of water. Then after the fish has fainted, the fish was dried using a cloth and the weight of the fish is weighed to determine the dose of ovaprim. The dose of ovaprim for male and female botia broodstock according to Putra et al (2017) is $0.6 \times$ (mother weight / 1000). The broodstock was injected with ovaprim using a syringe on the underside of the dorsal fin. The injected broodstock was then returned to the broodstock quarantine aquarium to wait for the latent time to end. The spawned broodstock was 6 male and 2 female so that the ratio of the parent used was $3: 1$.

\subsection{Stripping}

The broodstock to be stripped were male and female who have been given spawning hormone stimulation. Before stripping, the male and female were anesthetized using $0.6 \mathrm{~mL}$ of phenoxyethanol in $2 \mathrm{~L}$ of water. The male was stripped first to take sperm. The striping process was done by massaging the belly of the botia fish until the milky white sperm come out. The sperm that comes out was then sucked using a $1 \mathrm{~mL}$ syringe that has been added with $0.3 \mathrm{~mL}$ of $\mathrm{NaCl}(0.9 \%)$. The sperm was then inserted into a microtube which was used as a storage area for sperm. Striping of female broodstock was carried out to isolate eggs from the female body. Similar to the striping process in male, females were massaged on their stomachs slowly to push the eggs out of the their body.

\subsection{Fertilization}

The isolated sperm in the microtube was evenly poured into the basin for the eggs. The eggs and sperm were rinsed with $400 \mathrm{~mL}$ of water. The rinsing process was carried out for three times until the eggs were completely clean. The purpose of the flushing process was to activate the sperm and remove fat and dead sperm. Let the eggs that have been rinsed sit so that the eggs were at the bottom of the basin and the rinsed water was drained slowly.

\subsection{Eggs Hatching}

Fertilized botia eggs were spread into the hatchery funnel. After the eggs were in the hatchery funnel, the tap of the incubation tub was connected to the hose and the funnel was turned on to make the water pressure up so that the eggs would rotate from bottom to top. If the eggs were almost at the bottom of the funnel then the tap flow speed was increased so that the eggs could rotate following the current pressure.

\section{Results and Discussion}

\subsection{Broodstock Maintenance}

Broodstock of botia fish were kept in a special room completed with an air conditioner (AC) which was to keep the room temperature stable at $25^{\circ} \mathrm{C}$ to $26^{\circ} \mathrm{C}$. In addition, the room was also equipped with an automatic lighting adjustment tool that turned on for $12 \mathrm{~h}$ started at 06.00 a.m and turned off for $12 \mathrm{~h}$ started at 06.00 p.m. The lighting in the main maintenance room used red fluorescent lamps with 5 watt power.

The main maintenance area was made of a canvas tub in the circle shape and equipped with a fiber-based filter tub which was to filter water before it entered into the maintenance tank. The 
filter tank contained a bioball which was used as a biological filter and a dacron cloth which was used as a physical filter. Resirquation systems in broodstock maintenance utilized bulkheads and filter tub holes containing physical and biological filters so that water could flow from the top to the bottom. The broodstock of botia fish were fed earthworms (Lumbricus sp) as much as $10 \%$ of their body weight or as much as $300 \mathrm{~g}$. Before given to the broodstock of botia fish, earthworms were washed using water to remove dirt that sticked to the worm's body surface. According to Salawiyah (2007) states that botia fish feed in nature includes insects, mollusks, crustaceans, worms, arachnids, and algae.

Botia fish could be spawned artificially using the spawning hormone such as ovaprim. According to Sukendi (1995) ovaprim is a mixture of salmon analogues Gonadotropin Releasing Hormone $(\mathrm{GnRH})$ and anti-dopamine. Ovaprim is used to stimulate the function of the gonadotropin hormone in the fish body so that it can accelerate the ovulation and spawning process. The characteristics of botia broodstock that are good for breeding are no defects, $18 \mathrm{~cm}$ to $24 \mathrm{~cm}$, and have a total length of more than $12 \mathrm{~cm}$. The broodstock male has a smaller and slender body shape than the female. The male and female will release sperm and eggs, respectively, when they are stripped. The male has a flat stomach while the female parent has a bulging stomach. The male weight ranges from $22 \mathrm{~g}$ to $174 \mathrm{~g}_{\text {ind }}^{-1}$ while the female weighs are between $46 \mathrm{~g}$ to $251 \mathrm{~g}^{\text {ind }}{ }^{-1}$ (Putra et al, 2017).

Table 1. Differences between male broodstock and female broodstock of botia fish

\begin{tabular}{lll}
\hline No & Male broodstock & Female broodstock \\
\hline 1 & Small in size and slim body & Bigger in size \\
2 & Flat stomach & Belly bulge \\
3 & Release sperm when stripped & Release eggs when stripped \\
\hline
\end{tabular}

\subsection{Eggs Fecundity}

Fecundity is the number of eggs released by the female at ovulation (Putra et al. 2017). The fecundity calculation of the botia broodstock I having $44.2 \mathrm{~g}$ in size was 11712 eggs and fecundity of broodstock II of fish weighing 27.6 was 5195 eggs. The difference in the number of fecundities was caused by differences in broodstock weight. According to Makmur (2006), fecundity can increase logarithmically along with length or weight of the fish. The fecundity values of the two broodstock of botia fish were still in the normal range. According to Satyani et al. (2007), good botia fish fecundity ranges from 3000 eggs to 20000 eggs for a fish body weight of $70 \mathrm{~g}$ to $150 \mathrm{~g}$.

\subsection{Fertilization Rate (FR)}

Fertilization rate or degree of fertilization shows the percentage of fertilized eggs from all eggs released by the female during spawning (Putra et al, 2017). The FR value of female broodstock I was $90.4 \%$ and broodstock II was $81.9 \%$. The average FR of the two broodstock was $86.15 \%$. Unfertilized botia fish eggs looked cloudy white while fertilized botia fish eggs were clear white. Unfertilized eggs can be caused by poor egg and sperm quality and the ratio between sperm and egg counts was not appropriate. This was also expressed by Setyono (2009) who stated that sperm quality could affect the fertilization process. Tang \& Afandi (2001) explained that high sperm concentration could reduce sperm motility so that it is difficult for sperm to find and penetrate the egg microfil cell. 


\subsection{Hatching Rate (HR)}

Hatching rate is the percentage of eggs that hatch into larvae. The hatching rate of botia brood I was $81.8 \%$ and brood II was $74.5 \%$. The average hatching rate of botia fish eggs from the two broodfish was $78.15 \%$. The value of the egg hatching rate of the two broodfish was still in normal conditions. According to Satyani et al (2007), the degree of good botia fish hatching was more than $45 \%$. The hatching rate of eggs could be influenced by the temperature and condition of the eggs. Liyana et al. (2019) explained that egg hatching is influenced by genetic factors from the eggs themselves, temperature, and oxygen that support the hatching process.

\section{Conclusion}

Botia fish spawning could be conducted artificially using spawning hormones. Their spawning obtained an average of total fecundity with 8 453, while an average fertility rate (FR) was $86.15 \%$. Meanwhile an average of hatching rate (HR) was $78.15 \%$.

\section{References}

Ariyanto E, Anwar S, Sofian. 2019. Indeks Prevalensi dan Intensitas Ektoparasit pada Ikan Botia (Chromobotia macracanthus) di Sumatera Selatan. Jurnal IImu-ilmu Perikanan dan Budidaya Perairan. 14 (1): 55-62.

Ghofur M, Harianto E. 2018. Inerja Produksi Ikan Botia (Chromobotia macracanthus) Padat Tebar Tinggi dengan Sistem Resirkulasi. Jurnal Akuakultur Sungai dan Danau. 3(1): 18-24.

Ghofur M, Sugihartono M, Aulia HD. 2018. Suhu Optimal untuk Kelangsungan Hidup Pemeliharaan Larva Ikan Botia (Chromobotia macracanthus). Jurnal Akuakultur Sungai dan Danau. 3(2): 5055.

Kusrini E, Cindelaras S, Prasetio AB. 2015. Pengembangan Budidaya Ikan Hias Koi (Cyprinus carpio) Lokal Di Balai Penelitian dan Pengembangan Budidaya Ikan Hias Depok. Media Akuakultur. 10(2): 71-78.

Liyana SH, Sari LA, Agustono. 2019. Evaluasi Pengaruh Hormon Gonadotropin pada Tingkat Kematangan Gonad Ikan Botia (Chromobotia macracanthus). Jurnal Perikanan Pantura. 2(2): 98-105.

Makmur S. 2006. Fekunditas dan Diameter Telur Ikan Gabus (Channa striata Bloch) di Daerah Banjiran Sungai Musi Sumatera Selatan. Jurnal Perikanan. 8 (2): 254-259.

Putra HFE, Rahardjo SSP, Permana A. 2017. Pemijahan Ikan Hias Botia (Chromobotia macracanthus Bleeker) Secara Buatan dengan Injeksi Hormon HCG (Human Chorionic Gonadotrophin) dan LHRH-a (Luteinizing Hormone Releasing Hormone-Analog). Journal of Aquacultur and Fish Health. 6(3): 101-109.

Salawiyah SRN. 2007. Kebiasaan Makan Ikan Botia (Chromobotia macracanthus) Di Daerah Aliran Sungai Musi, Sumatera Selatan. Skripsi. Respository IPB. 15-16.

Satyani D, Mundriyanto, Subandiyah H, Sudarto F, Taufik, Slembrouck J, Legendre M, Pouyaud L. 2007. Teknologi Pembenihan Ikan Hias Botia (Chromobotia macracanthus Bleeker) Skala Laboratorium. Loka Riset Budidaya Ikan Hias Air Tawar dan Institute de Recherche pour le Development. pp.12. 
Setyono B. 2009. Pengaruh Perbedaan Konsentrasi Bahan pada Pengenceran Sperma Ikan 'Skim Kuning Telur" Terhadap Laju Fertilisasi, Laju Penetasan dan Sintasan Ikan Mas (Cyprinus carpio). GAMMA. 5(1): 6-13.

Sukendi. 1995. Pengaruh Kombinasi Penyuntikan Ovaprim dan Prostaglandin F2a Terhadap Daya Rangsang Ovulasi dan Kualitas Telur Ikan Lele Dumbo (Clarias gariepinus). Program Pascasarjana. Institut Pertanian Bogor. Jawa Barat. pp. 19.

Tang UM, Afandi R. 2001. Biologi Reproduksi Ikan. Pusat Penelitian Kawasasan Pantai dan Perairan. Universitas Riau. Riau. pp. 29.

Tridjoko D, Makatutu, Sugama K. 1996. Pengamatan Pemijahan dan Perkembangan Telur Ikan Kerapu Bebek (Cromileptes altivelis) pada Bak Secara Terkontrol. Jurnal Penelitian Perikanan Indonesia. 2(2): 55-59. 